\title{
Assessing the Success of Postfire Reseeding in Semiarid Rangelands Using Terra MODIS
}

\author{
Fang Chen, ${ }^{1}$ Keith T. Weber, ${ }^{2}$ and John L. Schnase ${ }^{3}$
}

Authors are ${ }^{1}$ Research Associate and ${ }^{2}$ Professor, GIS Training and Research Center, Idaho State University, Pocatello ID 83209, USA; and ${ }^{3}$ Senior Computer Scientist, Office of Computational and Information Science and Technology, NASA Goddard Space Flight Center, Greenbelt, MD 20771, USA.

\begin{abstract}
Successful postfire reseeding efforts can aid rangeland ecosystem recovery by rapidly establishing a desired plant community and thereby reducing the likelihood of infestation by invasive plants. Although the success of postfire remediation is critical, few efforts have been made to leverage existing geospatial technologies to develop methodologies to assess reseeding success following a fire. In this study, Terra Moderate Resolution Imaging Spectroradiometer (MODIS) satellite data were used to improve the capacity to assess postfire reseeding rehabilitation efforts, with particular emphasis on the semiarid rangelands of Idaho. Analysis of MODIS data demonstrated a positive effect of reseeding on rangeland ecosystem recovery, as well as differences in vegetation between reseeded areas and burned areas where no reseeding had occurred $(P<0.05)$. We conclude that MODIS provides useful data to assess the success of postfire reseeding.
\end{abstract}

\section{Resumen}

Esfuerzos exitosos de resiembra post-fuego pueden ayudar a los ecosistemas de pastizales para regenerarse rápidamente, estableciendo una comunidad deseable de plantas y reduciendo la probabilidad de infestación de plantas invasivas. Mientras el éxito del mejoramiento post-fuego es crucial, pocos esfuerzos se han hecho para aprovechar las tecnologías geospeciales existentes para desarrollar metodologías encaminadas a medir el éxito en la resiembra después de la presencia de fuego. En este estudio, información de satélite Terra Moderate Resolution Imaging Spectroradiometer (MODIS) se usó para mejorar la capacidad de determinar los trabajos de rehabilitación post-fuego, con un particular énfasis en los pastizales semiáridos de Idaho. Análisis de información de MODIS demostraron un efecto positivo de resiembra en la recuperación de los ecosistemas de pastizales así como en diferencias en vegetación entre áreas resembradas y áreas quemadas donde la resiembra no ha ocurrido $(P<0.05)$. Se concluyó que MODIS provee información útil para determinar el éxito de las resiembras post-fuego.

Key Words: fPAR, Idaho, rehabilitation, remote sensing, wildfire

\section{INTRODUCTION}

Wildfire is a common hazard in the semiarid rangelands of southeast Idaho. Following wildfire, ground vegetation typically is changed and can leave the landscape devoid of vegetative cover. These communities frequently undergo a series of adverse ecological changes, such as soil erosion, invasion by introduced annual grasses (e.g., cheatgrass [Bromus tectorum] and Medusahead [Taeniatherum caput-medusae]), and long-term native species decline (Pierson et al. 2002; Hilty et al. 2004). Rehabilitation is often necessary after fire, particularly in areas with high variation of the terrain. Monitoring how ecological systems respond to rehabilitation efforts is a critical step for determining long-term sustainability of the communities affected and for planning future land management practices.

Over the years, increasing resources have been devoted to fire rehabilitation efforts through various federal agencies such as the US Department of Agriculture (USDA), Forest Service

\footnotetext{
This study was made possible by grants from the National Aeronautics and Space Administration Idaho Space Grant Consortium (subaward: FPK100-SB-004) and the National Aeronautics and Space Administration Goddard Space Flight Center (NNX08A090G).

Correspondence: Fang Chen, GIS Training and Research Center, Idaho State University, 921 S 8th Ave, Stop 8104, Pocatello ID 83209, USA. Email: chenfang@isu.edu
}

Manuscript received 24 August 2011; manuscript accepted 29 May 2012.
(USFS), the US Department of the Interior-Bureau of Land Management (BLM), and the National Park Service (NPS), and many efforts have been made to monitor postfire recovery of ecosystems in southeast Idaho (Beyers 2004; Weber 2010). In particular, the USFS, BLM, and NPS have proposed a series of recovery projects focused on better understanding the effects of fire along the wildland-urban interface (WUI), where certain human activities (e.g., prescribed fire and grazing) can negatively impact and potentially accelerate interrelated ecological changes. The objectives of these projects were to identify ways to prevent soil erosion, water loss, and the permanent impairment of ecosystems along the WUI (Gibbons 1995; Ercanoglu et al. 2006).

Many wildfire studies indicate that successful postfire reseeding aids in the rapid establishment of a desired plant community and assists in the recovery of the ecosystem (Hubbard 1975; Beyers 2004). Fires consume the protective vegetation and organic litter cover from hillsides, which destabilizes the soil surface on steep slopes. Reseeded plants can rapidly stabilize soils and promote water infiltration. Furthermore, successful reseeding treatments can better control erosion and prevent loss of topsoil (Anderson and Brooks 1975; Beyers 2004). In New Mexico, postfire reseeding decreased soil loss after the Cerro Grande Fire (Miller et al. 2003), and similarly, postfire reseeding reduced hill slope erosion after the 1998 North 25 Fire in north central Washington (Robichaud et 
al. 2006). Reseeding also can increase the availability and quantity of range forage for both wildlife and livestock and help control the spread of invasive plants on public lands when using optimal initial plant establishments (Hubbard 1975; Sheley et al. 1997; Eiswerth et al. 2009).

Many factors affect the success of postfire reseeding, including the initial choice of plant species (Martin and Wilsey 2006), mechanical and nonmechanical treatments used for planting (Ott et al. 2003), soil conditions (Gillen and Berg 1998), terrain (Miles et al. 1989), and precipitation (Robichaud et al. 2006). Various assessment approaches have been developed to measure reseeding success and the impact of reseeding on the ecosystem. The focus of these assessment approaches can be categorized into one of three ecosystem attribute appraisals: 1) biodiversity and vegetation type (SER 2004; Ruiz-Jaen and Aide 2005); 2) vegetation structure (Peterson et al. 1998); and 3) ecological processes (e.g., vegetation productivity) (Allen 1993; Wilkins et al. 2003). Although the BLM's emergency fire rehabilitation (EFR) funds have been used to monitor reseeding efforts (US General Accounting Office 2003) since the mid-1980s, few efforts have used geospatial technologies to accomplish this task (Miller et al. 2003). In contrast, most assessments have relied upon field measurements comparing ecosystem attributes in restored sites with corresponding attributes at reference sites (SER 2004). Although these conventional assessments are straightforward and accurate for small-scale studies, they also are labor-intensive and can be difficult to implement across the vast fire areas common to the intermountain West. Due to the large expanse of Idaho rangelands, coupled with the heterogeneity and variability of vegetation in semiarid ecosystems, field-based methods are limited in assessing postfire reseeding success and ecosystem recovery over an entire region as compared to the synoptic view provided with remote sensing technology.

Satellite remote sensing has the ability to perform land assessments over large spatial areas with frequent periodicity. The Moderate Resolution Imaging Spectroradiometer (MODIS) is a key instrument aboard the Terra and Aqua satellites. One of the derived products developed by the MODIS Land Discipline Team (MODLAND) for the MODIS sensor is the fraction of photosynthetically active radiation (fPAR) product that provides global $1 \mathrm{~km}$ spatial resolution fPAR imagery at 8-d intervals (Knyazikhin et al. 1998; Myneni et al. 2002). fPAR is directly related to the top of canopy spectrum and measures the proportion of available radiation in specific photosynthetically active wavelengths (i.e., $0.4-0.7 \mu \mathrm{m}$ ) that are absorbed by the plant canopy (Chen 1996; Cramer et al. 1999; Hély et al. 2003; Chen et al. 2010). In many ecological studies, fPAR has been used to represent vegetation characteristic (e.g., vegetation cover, density, and biomass) within several biomes (Bonan 1995; Chen et al. 2008).

In this study, we used MODIS fPAR products to generate layers of primary productivity from 2004 to 2009. Geospatial technologies and earth observation data were used to improve the capacity to assess postfire reseeding rehabilitation efforts, with particular emphasis on the semiarid rangelands of Idaho. Our study addressed two objectives: 1) Assess postfire reseeding success using geospatial technologies in the semiarid rangelands of Idaho; and 2) Evaluate the effect of reseeding projects on postfire ecosystem recovery of semiarid rangelands.

\section{MATERIALS AND METHODS}

\section{Study Area}

The study area of the conducted research focused on the Big Desert area in southeast Idaho (Fig. 1). The area lies approximately $71 \mathrm{~km}$ northwest of Pocatello Idaho, and with the center of the study area is located at lat $43^{\circ} 14^{\prime} 27.88^{\prime \prime} \mathrm{N}$ and long $113^{\circ} 4^{\prime} 18.68^{\prime \prime} \mathrm{W}$. Large portions of the Big Desert are managed as grazing allotments by the BLM. The area is a semiarid sagebrush-steppe ecosystem with a high proportion of bare ground (bare ground $\sim 17 \%$ ), and with a vegetation component consisting of primarily native and nonnative grasses, forbs, and many shrub species, including sagebrush (Artemisia tridentata subsp. wyomingensis) and rubber rabbitbrush (Chrysothamnus nauseosus) (West 1999; West and Young 2000). The elevation of the study area ranges from $1349 \mathrm{~m}$ to $2297 \mathrm{~m}$ above sea level, and annual precipitation is $230 \mathrm{~mm}$ with $40 \%$ of the precipitation falling from April through June.

In 2006, the Big Desert study area was the site of a large lightning-caused wildfire. The Crystal Fire, one of the largest fires in southeast Idaho since 1936, burned approximately $40 \%$ of the Big Desert study area. The Crystal Fire burned approximately 89117 ha of grasslands and sagebrush between August 15 and August 31, 2006, and more than 16100 ha burned in a single day. Although this large-scale disturbance had the potential to adversely affect the rangeland ecosystem of southeast Idaho for a decade or more (Ojima et al. 1994; Nelle et al. 2000), it also presents scientists with a unique opportunity to monitor and assess postfire reseeding efforts and ecosystem recovery within this study area.

\section{Rehabilitation Plan and Field Survey}

To assist in the recovery of the rangelands ecosystem, the Idaho state office of the BLM developed a 3-yr reseeding plan for the "Crystal Fire Burned Area Rehabilitation," with estimated costs exceeding \$2M (Hankins 2008). The reseeding plan included ground seeding, aerial seeding, and plug planting. Ground seeding was conducted along with cheatgrass herbicide treatments, native grass seeding, and sagebrush drill seeding (Fig. 1). Herbicide treatments were conducted within homestead, butte native, and sagebrush-plug reseeding areas which began in the spring of 2007 using a contract helicopter or fixedwing aircraft flying at low altitude. Herbicide was applied at a low rate $\left(95.82 \mathrm{~mL} \cdot \mathrm{ha}^{-1}\right)$ so existing perennial native bunchgrasses would not be killed. After reducing the abundance of existing exotic invasive annuals, native grass seeding and sagebrush drill seeding were conducted and completed in the fall 2007. Between fall 2007 and spring 2008, sagebrush plug planting was conducted to re-establish Wyoming big sagebrush. In addition, to help establish sagebrush from seed over a portion of the burned area, sagebrush aerial seeding was conducted using a whirlybird spreader attached to a utility 


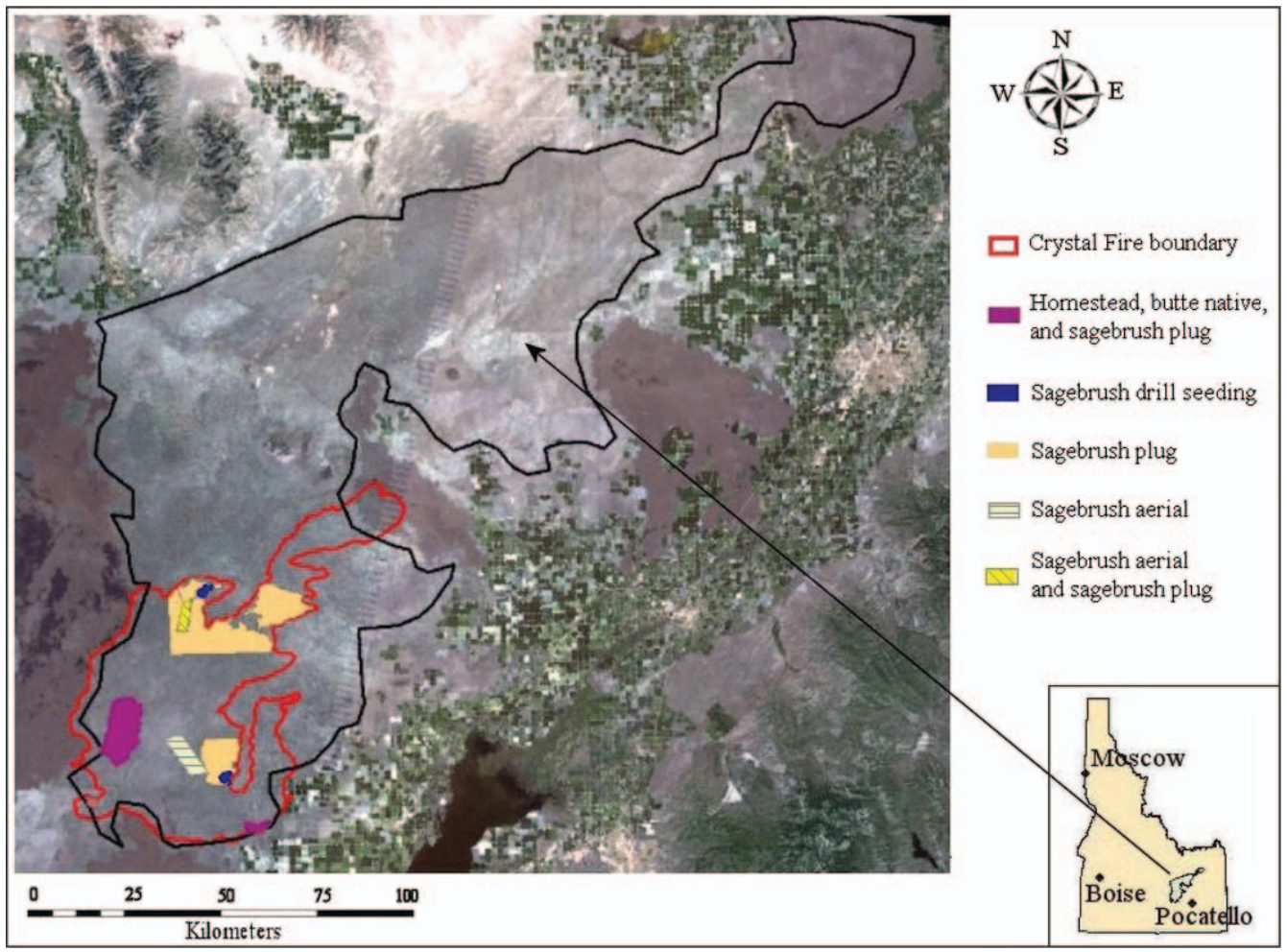

Figure 1. Location of the Big Desert study area in southeast Idaho and each reseeding treatments within the Crystal fire perimeter which burned in 2006.

terrain vehicle (UTV) in the winter of 2008 (December 2008; Table 1) (Peterson et al. 2009).

In June 2008, these areas were visited by BLM personnel to examine the effectiveness of reseeding. Sample plots $(n=24)$ were established in each seeding area and in adjacent unseeded areas. Twenty Daubenmire frames placed along a 30.48-m line transect were used to determine vegetative cover and density in both reseeded and control sites (Daubenmire 1959; Hanley 1978).

\section{MODIS Image Processing}

A series of Collection 5 MODIS fPAR (MOD15A2) scenes were selected for 2004 to 2009 (1-km spatial resolution and a time interval of $8 \mathrm{~d}$ ), and projected into Idaho Transverse Mercator projection (IDTM), NAD 83, using ESRI's ArcGIS 9.3 for datum transformation and projection (ESRI 2011). Using quality control (QC) layers, MODIS fPAR data were screened to reject data of insufficient quality. Only pixels with the best possible quality (i.e., values on all bit fields were equal to zero) under the QC definition table were retained (Table 2). MODIS quality assessment (QA) is an integral part of the MODIS Land production chain. The objective of MODLAND QA is to evaluate and document the scientific quality of the MODLAND products with respect to their intended performance.
Quality assessment information are provided by QC layers, and checking these QC layers can ensure that MODIS individual product was generated without error or artifacts. In this study, the QC filter includes pixels with good quality and removes pixels that were impaired by cloud cover or other calibration errors created by the sensor.

Using a single fPAR scene to characterize vegetation likely would result in an underestimation of annual productivity, because a single fPAR image might not capture the maximum fPAR value for each pixel over an entire growing season. For instance, within the Big Desert, cool-season grasses such as cheatgrass (Bromus tectorum) germinate and "green-up" early in the growing season (e.g., April and May) and then quickly senesce (June and July). During the senescent period of Bromus tectorum, native grasses such as Indian rice grass (Oryzopsis bymenoides) and needle-and-thread (Stipa comata) are actively growing and achieving peak biomass. Therefore, using Idrisi Taiga (v16.03) remote-sensing data-processing software (Clark Labs 2011), 8-d composite fPAR scenes for April through September were used as input layers to calculate monthly composite fPAR layers for the study area, where the output value of each pixel represented the maximum fPAR value of each pixel among the set of input layers. Monthly composite fPAR layers were used to better characterize the vegetation

Table 1. Summary of reseeding treatment areas following the 2006 Crystal Fire.

\begin{tabular}{lccccc}
\hline & \multicolumn{4}{c}{ Treatment type } \\
\cline { 2 - 5 } & Homestead $^{1}$ & Mule butte native grass & Sagebrush drill & Sagebrush plug & Sagebrush aerial \\
\hline Total area (ha) & 527 & 3726 & 405 & 405 & 4050 \\
\hline 1'Anatone' bluebunch wheatgrass, 'Nordan' Crested wheatgrass, 'Nezar' Indian ricegrass, 'Sodar' streambank wheatgrass, and 'Eski' sanfoin were reseeded at Homestead areas
\end{tabular}

\footnotetext{
1'Anatone' bluebunch wheatgrass, 'Nordan' Crested wheatgrass, 'Nezpar' Indian ricegrass, 'Sodar' streambank wheatgrass, and 'Eski' sanfoin were reseeded at Homestead areas.
} 
Table 2. Moderate resolution imaging spectroradiometer fraction of photosynthetically active radiation (MODIS fPAR) general quality control definitions for collection 5 data.

\begin{tabular}{|c|c|c|c|}
\hline Bit no. & Parameter name & Bit combination & Description of bitfield(s) \\
\hline \multirow[t]{2}{*}{0} & MODLAND_QC_bits & 0 & Good quality (main algorithm with or without saturation) \\
\hline & & 1 & Other quality (back-up algorithm or fill values) \\
\hline \multirow[t]{2}{*}{1} & Sensor & 0 & Terra \\
\hline & & 1 & Aqua \\
\hline \multirow[t]{2}{*}{2} & DeadDetector & 0 & Detectors apparently fine for up to $50 \%$ of channels 1,2 \\
\hline & & 1 & Dead detectors caused $>50 \%$ adjacent detector retrieval \\
\hline \multirow[t]{4}{*}{$3-4$} & CloudState (inherited from & 00 & 0 Significant clouds NOT present (clear) \\
\hline & Aggregate_QC bits $[0,1]$ cloud state) & 01 & 1 Significant clouds WERE present \\
\hline & & 10 & 2 Mixed cloud present on pixel \\
\hline & & 11 & 3 Cloud state not defined, assumed clear \\
\hline \multirow[t]{5}{*}{$5-7$} & SCF_QC ${ }^{1}$ (five-level confidence score) & 000 & 0, Main $(\mathrm{RT})^{2}$ method used, best result possible (no saturation) \\
\hline & & 001 & 1, Main (RT) method used with saturation. Good, very usable \\
\hline & & 010 & 2, Main (RT) method failed due to bad geometry, empirical algorithm used \\
\hline & & 011 & 3, Main (RT) method failed due to problems other than geometry, empirical algorithm used \\
\hline & & 100 & $\begin{array}{l}\text { 4, Pixel not produced at all, value couldn't be retrieved (possible reasons: bad L1B data, } \\
\text { unusable MODAGAGG }{ }^{3} \text { data) }\end{array}$ \\
\hline
\end{tabular}

${ }^{1}$ SCF QC indicates the self-consistent field quality control.

${ }^{2} \mathrm{RT}$ indicates radiative transfer.

${ }^{3}$ MODAGAGG indicates MODIS daily aggregated surface reflectance product.

across the dynamic study site where distinct vegetation communities (grasses, forbs, and shrubs) experience divergent periods of peak biomass and/or greenness.

A total of 460 randomly distributed test points were generated over the Crystal Fire area using Hawth's analysis tools for ESRI's ArcGIS 10.0 within both reseeding (Re) areas $(n=230)$ and no reseeding (NRe) areas $(n=230)$ (Spatial Ecology, LLC 2011). After removing all points falling within the "bad data quality" areas of the imagery $(n=193$ and 178 remained in the Re and NRe areas, respectively), fPAR pixel values were extracted from monthly composite layers using the ArcGIS "Sample" tool. Mean monthly fPAR values of sample test points were then calculated for Re (overall reseeding areas, $n=193$; homestead and mule butte native, $n=54$; sagebrush drill, $n=19$; sagebrush plug, $n=94$; sagebrush aerial, $n=26$ ) and NRe $(n=178)$ areas, respectively. To further quantitative assessment of fPAR differences between reseeding areas (Re) and burned areas where no reseeding had occurred (NRe), the mean monthly fPAR of sample points data were exported to SPSS V17.0 statistics software (IBM 2011) for regression analysis, a $t$ test was conducted and used to quantitatively assess whether fPAR values in Re areas were statistically different from fPAR values in NRe areas.

\section{RESULTS AND DISCUSSION}

Monthly composite fPAR values across the entire Re areas (including homestead, mule butte native, sagebrush drill, sagebrush plug, and sagebrush aerial seeding areas) and NRe areas were relatively similar between 2004 and 2007, suggesting very similar ground vegetation cover in $\mathrm{Re}$ and $\mathrm{NRe}$ areas. However, Re areas were substantially higher than NRe in 2008 (0.027, $P=0.009$ [May]; 0.023, $P=0.000$ [June]; $0.020, P=0.004$ [July]; 0.011, $P=0.000$ [August]; 0.004,
$P=0.016$ [September]) and $2009(0.012, P=0.370$ [May]; $0.019, P=0.003$ [June]; $0.025, P=0.000$ [July]; 0.006, $P=0.002$ [August]; 0.003, $P=0.098$ [September]) (Table 3 and Fig. 2). In comparison to NRe areas, fPAR values in $\mathrm{Re}$ areas increased $9 \%, 8 \%, 10 \%, 7 \%$, and $3 \%$ from May to September in 2008 and $4 \%, 7 \%, 11 \%, 4 \%$, and $2 \%$ from May to September in 2009. fPAR values were higher in Re areas, indicating that increased ground cover was established and higher rates of photosynthetic activity were observed in the Re area. It is clear that reseeding had a positive effect on the primary productivity of these areas, as evidenced by the continued elevated values through September in both 2008 and 2009.

Between August 2006 and October 2007, before the postfire reseeding project began, ground vegetation conditions were very similar in both $\mathrm{Re}$ and $\mathrm{NRe}$ areas. Interestingly, the

Table 3. Difference in monthly composite fraction of photosynthetically active radiation (FPAR) values between reseeding areas (Re) and no reseeding areas (NRe).

\begin{tabular}{clcccc}
\hline \multicolumn{2}{c}{ fPAR composite } & & \multicolumn{3}{c}{ Reseeding areas vs. NRe areas } \\
\cline { 1 - 2 } \cline { 4 - 5 } Year & Month & & fPAR change & Rate of change (\%) & $P$ value $^{1}$ \\
\hline 2008 & May & & 0.027 & 9 & 0.009 \\
& June & & 0.023 & 8 & 0.000 \\
& July & & 0.020 & 10 & 0.004 \\
& August & & 0.011 & 7 & 0.000 \\
& September & & 0.004 & 3 & 0.016 \\
& May & & 0.012 & 4 & 0.370 \\
& June & & 0.019 & 7 & 0.003 \\
& July & & 0.025 & 11 & 0.000 \\
& August & 0.006 & 4 & 0.002 \\
& September & 0.003 & 2 & 0.098 \\
\hline
\end{tabular}

${ }^{1}$ A $t$ test was conducted to calculate $P$ value. 

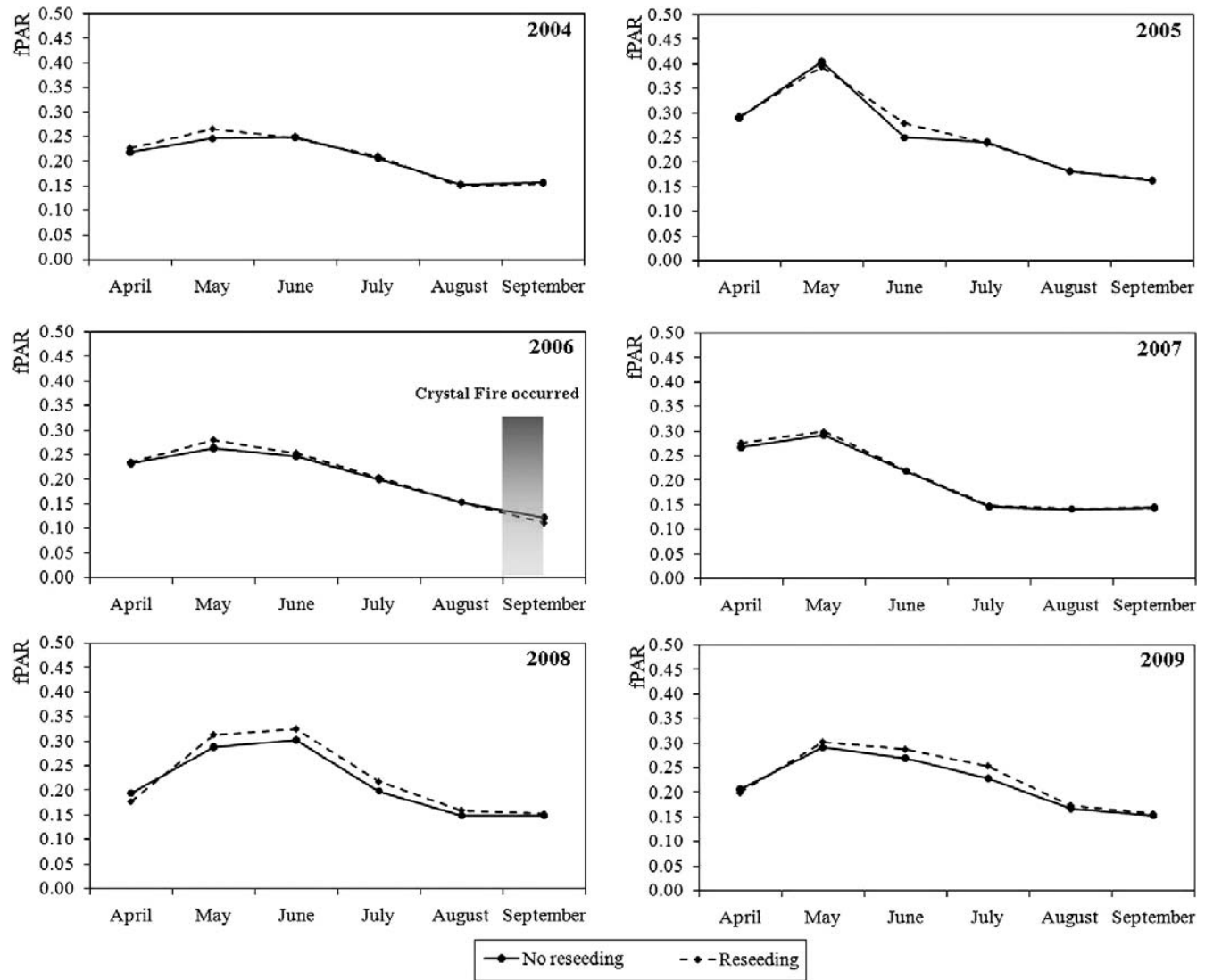

Figure 2. Monthly composite fraction of photosynthetically active radiation (fPAR) values within reseeding (Re) and no reseeding (NRe) areas. Re areas include homestead, mule butte native, sagebrush drill, sagebrush plug, and sagebrush aerial seeding treatments areas. As can be seen, fPAR can be used to visualize ground vegetation differences between Re and NRe areas from 2004 to 2009.

smallest difference in fPAR between the entire Re and NRe areas was observed between April to September, 2007 (Fig. 2). Results from $t$ test analyses revealed monthly composite fPAR values were statistically different $(P<0.05)$ between Re and NRe areas in 2008 and between the majority of the 2009 growing season (June through August) (Table 4).
During the 2008 field survey conducted by the BLM, no Wyoming big sagebrush seedlings were found within the sagebrush drill seeding areas and subsequently, the sagebrush drill treatments were considered unsuccessful. Using MODIS imagery, no significant difference in fPAR was detected between sagebrush drill seeding areas and NRe areas during the same

Table 4. Results of $t$ test analyses comparing fraction of photosynthetically active radiation (fPAR) values within reseeding areas (Re) and no reseeding areas (NRe).

\begin{tabular}{|c|c|c|c|c|c|c|c|}
\hline \multicolumn{2}{|c|}{ fPAR composite } & \multicolumn{2}{|c|}{ Sagebrush drill vs. $\mathrm{NRe}^{1}$} & \multicolumn{2}{|c|}{ Sagebrush plug vs. NRe } & \multicolumn{2}{|c|}{ Overall vs. $\mathrm{NRe}^{2}$} \\
\hline Year & Month & $F$ value & $P$ value & $F$ value & $P$ value & $F$ value & $P$ value \\
\hline \multirow[t]{4}{*}{2008} & April & 0.045 & 0.241 & 1.199 & 0.022 & 0.408 & 0.043 \\
\hline & June & 0.712 & 0.168 & 24.375 & 0.000 & 14.362 & 0.000 \\
\hline & July & 0.682 & 0.148 & 2.191 & 0.000 & 0.055 & 0.004 \\
\hline & August & 14.024 & 0.103 & 9.210 & 0.000 & 12.637 & 0.000 \\
\hline \multirow[t]{5}{*}{2009} & April & 0.579 & 0.594 & 0.085 & 0.002 & 0.312 & 0.556 \\
\hline & May & 14.815 & 0.000 & 4.136 & 0.045 & 0.113 & 0.370 \\
\hline & June & 0.695 & 0.013 & 0.042 & 0.000 & 1.716 & 0.003 \\
\hline & July & 8.764 & 0.002 & 3.620 & 0.000 & 16.362 & 0.000 \\
\hline & August & 0.378 & 0.651 & 3.734 & 0.000 & 9.654 & 0.002 \\
\hline
\end{tabular}

${ }^{1}$ Sagebrush drill areas represent areas only conducted by sagebrush drill treatments.

${ }^{2}$ Overall reseeding areas represent all reseeding areas including homestead, mule butte native, sagebrush drill, sagebrush plug, and sagebrush aerial reseeding treatments. 


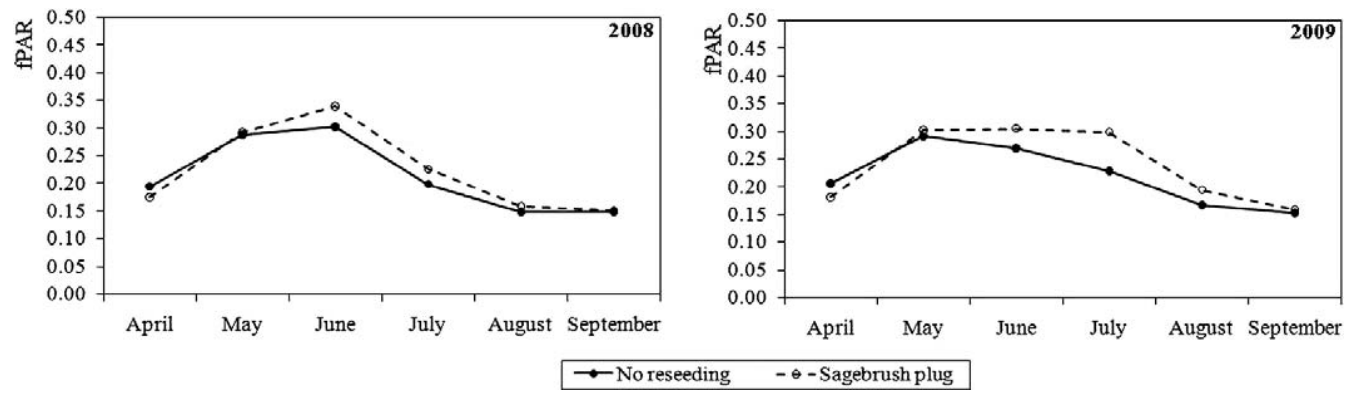

Figure 3. Monthly composite fraction of photosynthetically active radiation (fPAR) values in sagebrush plug reseeding areas (Re) and no reseeding areas (NRe). These graphs demonstrate the positive effects of reseeding efforts in sagebrush plug reseeding areas.

time period (June 2008; $P>0.05$ ), thereby corroborating BLM field results. However, between May through July 2009, MODIS monthly composite fPAR data indicated significant differences between these same areas.

In contrast to sagebrush drill seeding areas, 2008 field survey data indicate that sagebrush plug reseeding areas had a relatively high survival rate $(31 \%)$. fPAR values comparing sagebrush plug reseeding areas and NRe areas also demonstrated statistically significant differences $(P<0.05)$ from June through August, 2008 and throughout 2009. In comparison to $\mathrm{NRe}$ areas, fPAR values in sagebrush plug Re areas increased $2 \%, 12 \%, 14 \%, 7 \%$, and 2\% from May to September in 2008 and $4 \%, 13 \%, 31 \%, 16 \%$, and $4 \%$ in 2009 (Fig. 3). Higher fPAR values in the sagebrush plug $\mathrm{Re}$ areas demonstrate the reseeding project likely helped increase sagebrush cover and density.

In the semiarid rangelands of Idaho, many herbaceous plants, and especially introduced annual grasses, tend to be green only during active growth periods. In contrast, most shrubs maintain greenness when grasses senesce, resulting in a substantial reduction in observed fPAR (e.g., the fPAR value of a pure grass area is close to 0 ) late in the summer. Field survey data demonstrate that both native perennial grasses and annual grasses such as cheatgrass, regenerated in both Re and NRe areas with comparable estimates of total plant density in each (e.g., 180 density-plants $\cdot \mathrm{m}^{-2}$ in mule butte native and homestead reseeding area; 187 density-plants $\cdot \mathrm{m}^{-2}$ in unseeded area). The natural regeneration of Wyoming big sagebrush requires a longer time period, and therefore fewer plants were expected in NRe areas compared to the Re area. The increase in monthly composite fPAR values between June and August in 2008 and 2009 (Fig. 3) was attributed to fewer Wyoming big sagebrush plants in the NRe areas.

BLM field survey data demonstrated that reseeding treatments had an effect on the generation of perennial native grasses and annual invasive grasses such as cheatgrass. For example, in 2008, the density of perennial grasses in the mule butte native grass reseeding area was about twice that found in the unseeded area. In addition, whereas cheatgrass was more prevalent in the Re areas compared to the NRe areas, the density of perennial grasses in the homestead Re area was about the same as that found in the NRe area. The Homestead treatment also resulted in fewer cheatgrass plants within the Re area than were found in the NRe area.

MODIS fPAR data cannot detect the difference between perennial native grasses and annual invasive grasses such as cheatgrass. Thus, it was not possible to assess reseeding success of native grasses. However, Morisette et al. (2006) concluded that MODIS Normalized Difference Vegetation Index (NDVI) and Enhanced Vegetation Index (EVI) could be used to map invasive tamarisk (Tamarix spp.) habitat suitability in the United States, and this method also might be useful for mapping native and invasive grasses based on MODIS data. Future work will seek to incorporate MODIS NDVI, EVI, and fPAR data for a more comprehensive assessment of reseeding success in the semiarid rangelands of Idaho.

\section{MANAGEMENT IMPLICATIONS}

In this study, remote sensing image analysis was used to aid in determining the success of postfire reseeding and the impact of human activity (reseeding using three management approaches), within a sagebrush-steppe ecosystem in southeastern Idaho. The implementation of these and similar remote sensing techniques by land managers 1) could improve regional-scale assessments of ecosystem recovery, 2) are more cost-effective than traditional ground-based assessments, and 3) broaden our understanding of how specific reseeding projects affect postfire recovery. Furthermore, we conclude that field-measurement methods continue to play a significant role in the assessment of reseeding effects, and although MODIS data alone cannot act as a substitute for field surveys, it certainly can complement field efforts and enhance future assessments.

\section{LITERATURE CITED}

Allen, M. F. 1993. Microbial and phosphate dynamics in a restored shrub steppe in southwestern Wyoming. Restoration Ecology 1:196-205.

Anderson, W. E., AND L. E. Brooks. 1975. Reducing erosion hazard on a burned forest in Oregon by seeding. Journal of Range Management 28:349-398.

BEYERS, J. L. 2004. Postfire seeding for erosion control: effectiveness and impacts on native plant communities. Conservation Biology 18:947-956.

Bonan, G. B. 1995. Land-atmosphere interactions for climate system models: coupling biophysical, biogeochemical, and ecosystem dynamical processes. Remote Sensing of Environment 51:57-73.

Chen, F., J. M. Tang, and Z. Niu. 2008. Estimating the impact of urbanization on LAI/ PPAR in the Baltimore-Washington corridor area. Canadian Journal of Remote Sensing 34:326-337.

Chen, F., K. T. Weber, J. Anderson, and B. Gokhale. 2010. Comparison of MODIS LAI/ fPAR product with Landsat-5 TM LAI/fPAR over semiarid rangelands of Idaho. GIScience \& Remote Sensing 47:360-378. 
CHEN, J. M. 1996. Canopy architecture and remote sensing of the fraction of photosynthetically active radiation absorbed by boreal conifer forests. IEEE Transactions on Geoscience and Remote Sensing 34:1353-1368.

CLARK LABS. 2011. IDRISI Taiga GIS and Image Processing Software. Available at: http://www.clarklabs.org/products/idrisi-taiga.cfm. Accessed 1 July 2011.

Cramer, W., D. W. Kicklighter, A. Bondeau, B. Moore, G. Churkina, B. Nemry, A. Ruimy, AND A. L. SCHLoss. 1999. Comparing global models of terrestrial net primary productivity (NPP): overview and key results. Global Change Biology 5:1-15.

Daubenmire, R. F. 1959. A canopy-coverage method. Northwest Science 33:43-64.

Eiswerth, M. E., K. Krauter, S. R. Swanson, and M. Zielinski. 2009. Post-fire seeding on Wyoming big sagebrush ecological sites: regression analyses of seeded nonnative and native species densities. Journal of Environmental Management 90:1320-1325.

Ercanoglu, M., K. T. Weber, J. Langille, and R. Neves. 2006. Modeling wildland fire susceptibility using fuzzy systems. GIScience \& Remote Sensing 43:268-282.

ESRI. 2011. Coordinate systems, map projections, and geographic (datum) transformations. Available at: http://resources.esri.com/help/9.3/arcgisengine/ dotnet/89b720a5-7339-44b0-8b58-0f5bf2843393.htm. Accessed 1 July 2011.

GibBons, B. 1995. Remarks on postfire seeding. In: J. E. Keeley and T. Scott [EDs.]. Brushfires in California: ecology and resource management. Washington, DC, USA: International Association of Wildland Fire. p. 211.

GIllen, R. L., AND W. A. Berg. 1998. Nitrogen fertilization of a native grass planting in western Oklahoma. Journal of Range Management 51:436-441.

HankINS, J. 2008. Crystal fire monitoring summary. Idaho Falls, ID, USA: US Bureau of Land Management. $16 \mathrm{p}$.

Hanley, T. A. 1978. A comparison of the line-interception and quadrat estimation methods of determining shrub canopy coverage. Journal of Range Management 31:60-62.

Hély, C., P. R. Dowty, S. Alleaume, K. K. Caylor, S. Korontzl, R. J. Swap, H. H. Shugart, AND C. 0. JUSTICE. 2003. Regional fuel load for two climatically contrasting years in southern Africa. Journal of Geophysical Research (Atmospheres) 108:8475. 17 p. doi:10.1029/2002JD002341

Hilty, J. H., D. J. Eldridge, R. Rosentreter, M. C. Wicklow-Howard, and M. Pellant. 2004. Recovery of biological soil crusts following wildfire in Idaho. Journal of Range Management 57:89-96.

HuBBaRD, W. A. 1975. Increased range forage production by reseeding and the chemical control of knapweed. Journal of Range Management 28:406-407.

IBM. 2011. IBM SPSS Statistics. Available at: http://www-01.ibm.com/software/ analytics/spss/products/statistics/. Accessed 1 July 2011.

Knyazikhin, Y., J. V. Martonchik, R. B. Myneni, D. J. Diner, and S. W. Running. 1998. Synergistic algorithm for estimating vegetation canopy leaf area index and fraction of absorbed photosynthetically active radiation from MODIS and MISR Data. Journal of Geophysical Research 103:32257-32276.

Martin, L. M., AND B. J. WILSEY. 2006. Assessing grassland restoration success: relative roles of seed additions and native ungulate activities. Journal of Applied Ecology 43:1098-1109.

Miles, S. R., D. M. Haskins, and D. W. Ranken. 1989. Emergency burn rehabilitation: cost, risk, and effectiveness. Proceedings of the Symposium on Fire and Watershed Management; 26-28 October 1988; Sacramento, CA, USA. Berkeley, CA, USA: USDA Forest Service Pacific Southwest Forest and Range Experiment Station. General Technical Report PSW-109. p. 97-102.

Millek, J. D., W. J. Nyhan, AND S. R. Yool. 2003. Modeling potential erosion due to the Cerro Grande Fire with a GIS-based implementation of the Revised Universal Soil Loss Equation. International Journal of Wildland Fire 12:85-100.
Morisette, J. T., C. S. Jarnevich, A. Ullah, W. Cal, J. A. Pedelty, J. E. Gentle, T. J. Stohlgren, AND J. L. SCHNASE. 2006. A tamarisk habitat suitability map for the continental United States. Frontiers in Ecology and the Environment 4:11-17.

Myneni, R. B., S. Hoffman, Y. KnyazikHin, J. L. Privette, J. Glassy, Y. Tian, Y. Wang, X. Song, Y. Zhang, G. R. Smith, A. Lotsch, M. Friedl, J. T. Morisette, P. Votava, R. R. Nemanl, And S. W. Running. 2002. Global products of vegetation leaf area and fraction absorbed PAR from year one of MODIS data. Remote Sensing of Environment 83:214-241.

Nelle, P. J., K. P. Reese, And J. W. Connelly. 2000. Long-term effects of fire on sage grouse habitat. Journal of Range Management 53:586-591.

OJima, D. S., D. S. Schimel, W. J. Parton, And C. E. Owensby. 1994. Long- and shortterm effects on nitrogen cycling in tallgrass prairie. Biogeochemistry 24:67-84.

OtT, J. E., E. D. McArthur, And B. A. Roundy. 2003. Vegetation of chained and nonchained seedings after wildfire in Utah. Journal of Range Management 56:81-91.

Peterson, D. W., E. K. Dodson, and R. J. Harrod. 2009. Fertilization and seeding effects on vegetative cover after wildfire in north-central Washington State. Forest Science 55:494-502.

Peterson, G., C. R. Allen, and C. S. Holling. 1998. Ecological resilience, biodiversity, and scale. Ecosystems 1:6-18.

Pierson, F. B., D. H. Carlson, and K. E. Spaeth. 2002. Impacts of wildfire on soil hydrological properties of steep sagebrush-steppe rangeland. International Journal of Wildland Fire 11:145-151.

Robichaud, P. R., T. R. LILlybridge, And J. W. WagenBRenner. 2006. Effects of post-fire seeding and fertilizing on hillslope erosion in north-central Washington, USA. CATENA 67:56-67.

Ruiz-Jaen, M. C., And T. M. Alde. 2005. Restoration success: how is it being measured? Restoration Ecology 13:569-577.

[SER] Society for Ecological Restoration International Science \& Policy Working Group. 2004. The SER International Primer on Ecological Restoration. Available at: http:// www.ser.org. Accessed 1 July 2005.

Sheley, R. L., B. E. Olson, and L. L. LaRson. 1997. Effect of weed seed rate and grass defoliation level on diffuse knapweed. Journal of Range Management 50:39-43.

Spatial ECology, LLC. 2011. Hawths Tools. Available at: http://www.spatialecology. com/. Accessed 1 July 2011.

US General Accounting Office. 2003. Wildland fires: better information needed on effectiveness of emergency stabilization and rehabilitation treatments. GAO-03430. Available at: http://www.gao.gov/new.items/d03430.pdf. Accessed 1 July 2011.

WEBER, T. K. 2010. Forecasting rangeland condition in southeastern Idaho using GIS. Pocatello, ID, USA: GIS Training and Research Center, Idaho State University. Available at: http://giscenter.isu.edu/research/techpg/nasa_oneal/finalreport/ ch16.pdf. Accessed 20 July 2011.

WEST, N. E. 1999. Synecology and disturbance regimes of sagebrush steppe ecosystems. In: P. G. Entwistle, A. M. DeBolt, J. Kaltenecker, and K. Steenhof [comps.]. Proceedings: The Sagebrush-Steppe Ecosystems Symposium; 21-23 June 1999; Boise, ID, USA. Boise, ID, USA: Bureau of Land Management, Idaho State Office. p. 15-26.

WESt, N. E., AND J. A. Young. 2000. Intermountain valleys and lower mountain slopes. In: M. G. Barbour, \& W. D. Billings (EDS.). North American terrestrial vegetation. 2nd ed. New York, NY, USA: Cambridge University Press. p. 255-284.

Wikins, S., D. A. Keith, and P. Adam. 2003. Measuring success: evaluating the restoration of a grassy eucalypt woodland on the Cumberland Plain, Sydney, Australia. Restoration Ecology 11:489-503. 